( О. В. Руденко, доц., Заслужений художник України, КП। ім. Ігоря Сікорського, Київ, Україна

\title{
ГЕРБИ ТА ЕМБЛЕМИ УНІВЕРСИТЕТІВ СВІТУ ЯК ВСЕСВІТНЬОВІДОМІ БРЕНДИ ТА ЇХ АТРИБУТИКА
}

Проаналізовано історію створення емблематики закладів вищої освіти (ЗВО) деяких країн, системність підходів до їх знакових та геральдичних систем, створення брендованих емблематичних корпоративних конвенціональних засобів візуальної ідентифікації.

Вивчено історію емблематики Київського політехнічного інституту та КПІ ім. Ігоря Сікорського. Здійснено спроби унормування емблеми КПІ та запропоновано шляхи вдосконалення систем візуальної презентації ЗВО зі світовим ім'ям.

Ключові слова: символіка; геральдичний комплекс; іміджева презентація; брендинг; університет.

\section{Вступ}

Впізнаваність і своєрідна брендовість - невід'ємний атрибут усього якісного. Бажання підкреслити індивідуальність, вдосконалити іміджеву презентацію особи чи організації зумовлює необхідність створення відзнак, найбільш яскравими з яких $є$ геральдика та символіка.

Геральдичний символ або емблематичне зображення можливість через візуальний образ донести глибокий сенс.

У всі часи символіка Зво обирається з ретельністю.

Це однаково стосується гербів міст і знатних прізвищ, а також гербів навчальних закладів і факультетів. Цей підхід не випадковий, адже студенти та випускники протягом довгих років з гордістю згадують про свої студентські роки, зберігають документи та предмети, пов'язані з періодом їх навчання, навіть доповнюють одяг символами своєї Alma mater.

\section{Мета роботи}

На прикладах символіки ЗВО в Україні та інших країнах проаналізувати символіку КПІ ім. Ігоря Сікорського на предмет її відповідності законам геральдики та емблематики, традиціям європейської та світової символіки вищої освіти.

Одним з елементів такого дослідження $є$ світовий досвід відзначення почесного найменування у назві ЗВО - адже віднедавна КП। $€$ не просто технічним університетом, а й носить ім'я видатного свого випускника славетного конструктора авіаційної техніки, у першу чергу гелікоптерів, Ігоря Сікорського.

(c) 2019 p. 
Кінцевою метою є пропозиції унормовання й офіційного затвердження емблеми або герба КПІ ім. Ігоря Сікорського.

\section{Результати проведених досліджень}

Однією 3 істотних характеристик сучасного ринку освітніх послуг є зростаюча конкуренція ЗВО. Це стосується системи вищої професійної освіти. У сучасних умовах для забезпечення конкурентноспроможності 3ВО на ринку освітніх послуг необхідно вдосконалювати механізми підвищення ефективності його функціонування. Як один 3 найважливіших інструментів такої роботи розглядається брендинг 3BO.

Бренд ЗВО - це система ідентифікації та іміджевої презентації, що призначена для підвищення ефективності комунікації ЗВО з іншими агентами ринку освітніх послуг. Як компоненти образу ЗВО виділяють не матеріальні складники - статус у світовому чи національному рейтингу, історія розвитку ЗВО, місія, декларовані цінності, соціальнопсихологічний клімат організації та візуальні символи - знак, логотип, герб, фірмові корпоративні кольори тощо.

По-перше, довершений брендинг ЗВО сприяє його ідентифікації 3-поміж закладів-конкурентів. По-друге, бренд є інструментом, що дозволяє підвищити ефективність впровадження на ринок нових освітніх послуг. По-третє, бренд ЗВО підвищує впізнаваність навчального закладу в очах цільової аудиторії, а це зміцнює його конкурентні переваги.
Можна з упевненістю констатувати, що бренд ЗВО є важливою складовою управління іміджевим блоком діяльності університету чи іншого закладу освіти, поряд з науковим, фінансовоекономічним, організаційно-технічним, навчально-методичним та іншими блоками. Створення ефективного бренду та його успішне просування допускають систематичне відстеження сприйняття бренду цільовою аудиторією, а також оперативну корекцію елементів бренду ЗВО на основі результатів соціологічних і маркетингових досліджень.

3 найбільшим пієтетом до символіки своїх ЗВО ставляться на Заході.

Багато вчених, провідні політичні діячі та бізнесмени включають до свого гардеробу різні речі з символікою навчального закладу, який вони колись закінчили.

Серед таких речей: значок чи бутоньєрка в петлицю піджака, краватки в барвах коледжу або університету, запонки й затискачі до краватки з гербом свого ЗВО тощо.

Усесвітньо відомі, можливо завдяки частому згадуванню у кіно та літературі, персні випускників медичного факультету Гарвардського університету. Побачивши такий перстень на пальці лікаря, пацієнт, як правило, знаходить заспокійливу впевненість у тому, що потрапив у руки хорошого фахівця, який отримав якісну медичну освіту. Гарвардський значок у лацкані піджака адвоката $є$ запорукою якісно проведеного судового процесу, а значок з емблемою Сорбонни в будівельного підрядника засвідчує 
добірну якість будівлі, спорудженням якої керує випускник одного з найуславленішших ЗВО Франції та Європи (рис. 1).

Навіть короткий аналіз показує, що основними знаками символіки вищої освіти є саме геральдичні символи, адже герби підкреслюють давність заснування та надійність ЗВО, їх відданість традиціям, ґрунтовність і глибину знань.

На цьому наголошується шляхом успадкування історичних або створенням нових гербів. Відомо, що герб є однією з вищих форм емблематичного зображення, яке має особливості зображувальної форми. Це асоціюється з солідністю, стабільністю та респектабельністю.

Легко впізнається символіка Оксфордського університету найстарішого у світі ЗВО.

Гербу цього університету понад п'ятсот років: три золоті корони й товста книга з девізом і сімома застібками належить Оксфорду з XV століття, й за довгі роки він майже не зазнав змін.
Дослідники-геральдики, вважають, що сім застібок на книзі символізують сім основних предметів середньовічної освіти, «сім вільних наук/мистецтв» (лат. septim artes liberalis), якими вважалися: граматика; риторика; діалектика; арифметика; геометрія; астрономія; музика [1].

У той же час дослідники нагадують і про книгу, закриту сімома печатками, про яку говорив Іоанн Богослов: «І бачив я в правиці Того, Хто сидить на престолі, книгу, написану всередині і назовні, i запечатану сімома печатками».

Саме тому фраза з Одкровення св. Іоанна Богослова, девіз «Dominus Illuminatio Mea», що означає «Господь - світло моє», 3'явився на гербі приблизно 3 XVI століття.

Три золоті корони, на думку фахівців, символізують короля Едуарда Мученика, легендарного короля Артура та Ісуса Христа.

Уже в наші дні, в 1993 році до традиційного зображення герба був доданий оперізуючий синій

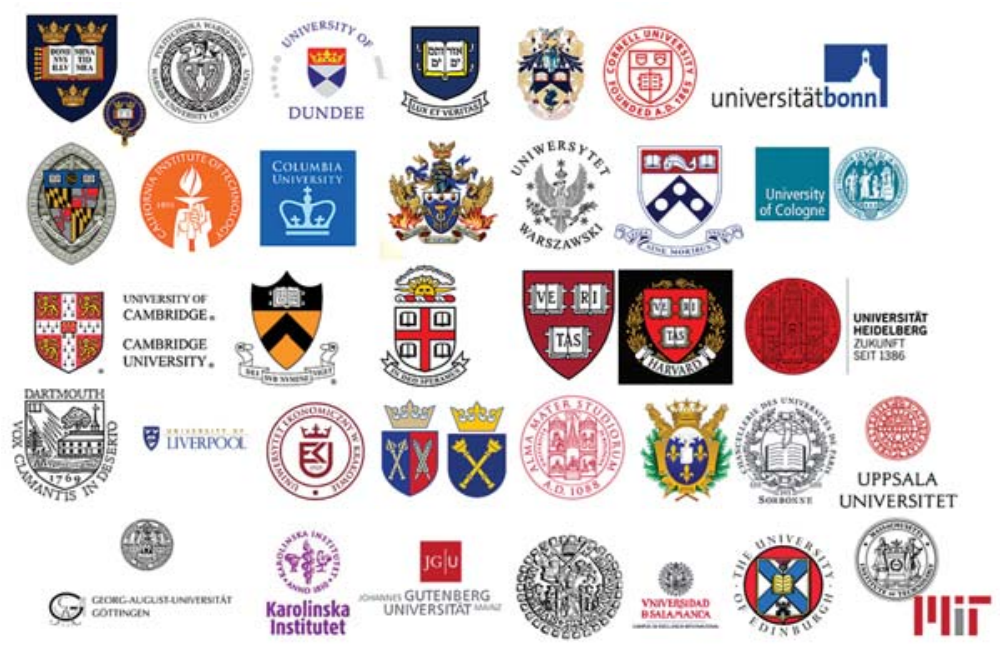

Рис. 1. Приклади символіки ЗВО у світі 


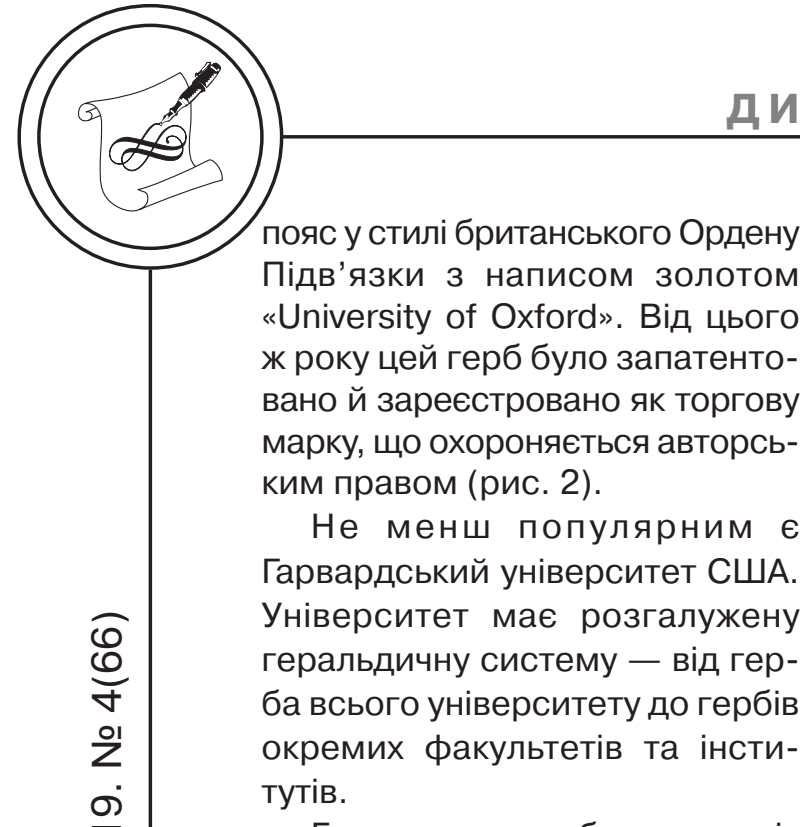

Гарвард - це бренд у всіх сенсах цього поняття, від якості освіти до якості життя. Практично кожен випускник цього університету вважає своїм обов'язком придбати кілька комплектів спортивної форми в барвах 3ВО та з символами свого університету й з гордістю носить її протягом усього свого життя.

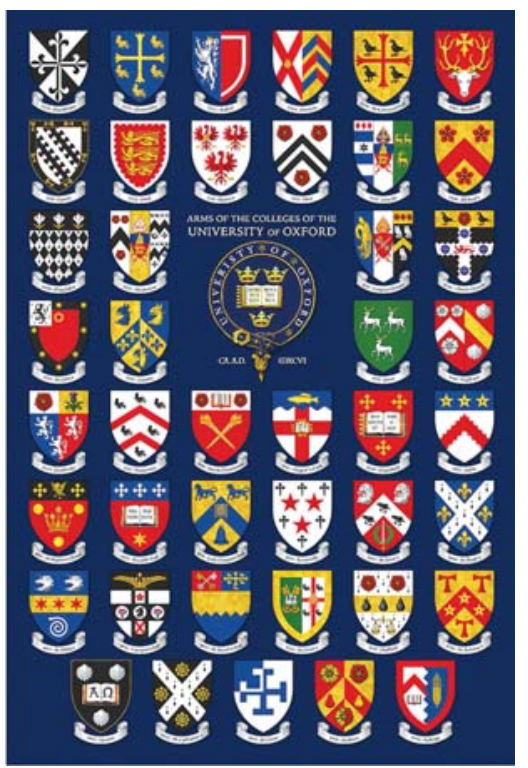

Рис. 2. Символіка Оксфордського університету
У Гарварді розвинена ціла індустрія з виробництва різних пам'ятних сувенірів з символікою університету та його факультетів. Персні 3 гербами факультетів Гарварду можна побачити в більшості провідних фахівців США та всього світу.

У Гарварду, як і в інших університетів, є свій девіз і традиційна символіка. Девіз Гарварду Veritas (лат. «Правда»), також з'являється на офіційному гербі університету, який являє собою пурпуровий геральдичний щит із трьома книжками, на яких тричі написно Veritas - Істина.

Крім того, в Гарварду є офіційний колір - пурпуровий або малиновий. Малиновий був офіційно призначений кольором Гарварду шляхом голосування гарвардськоих зборів у 1910 році.

Але чому був обраний саме малиновий? У 1858 році двоє учасників вітрильних гонок з команди Гарварду - Чарльз У. Еліот і Бенджамін У. Кроуніншілд, роздали іншим учасникам своєї команди малинові бандани, щоб глядачі могли відрізняти їх від інших учасників.

6 травня 1875 р., задовго до того, як малиновий колір університету був офіційно затверджений, студенти провели загальне голосування, де більшістю голосів був також обраний малиновий колір. Університетська газета, що видавалася з назвою The Magenta (колір маджента) у наступному випуску змінила їі на The Crimson (малиновий).

Еліот згодом став 21-шим президентом Гарварду та обіймав цю посаду від 1869 до 1909 року. Незабаром після того, як Еліот пішов у відставку, керівні 
збори університету остаточно вирішили зробити колір бандан яхтсменів 1858 року офіційним кольором університету.

Свої герби мають усі факультети та окремі інстутити Гарварду.

Зокрема, герб факультету медицини Гарварду був розроблений П'єром де Шаньйоном ля Розом, випускником медичного факультету 1895 року.

Створення та затвердження цього герба, поряд з гербами факультетів стоматології та охорони здоров'я, було приурочено до трьохсотріччя Гарвардського університету, що відзначалося 1936 р. У розробці герба також брали участь історики університету, які надали необхідну інформацію про геральдичні символи Гарварда й засновників відповідних факультетів.

При створенні цього герба автор скористався фамільними символами доктора Джона Уоррена, одного із затятих прихильників створення факультету медицини та першого професора факультету. Постать лева, що стоїть на задніх лапах, запозичено зі старовинного герба родини Уорренів (рис. 3).

Заслуговує на увагу ще один американський університет, що як і Гарвард, входить до знаменитої «Ліги Плюща», - університет Пенсільванії.

Ліга плюща (Ivy League) асоціація восьми найстаріших університетів Америки: Гарварду (Harvard), Прінстона (Princeton), Єля (Yale), Брауна (Brown), Колумбії (Columbia), Корнелла (Cornell), Дартмута (Dartmouth) та Пенсільванії (Pennsylvania). Ліга Плюща вважається еталоном престижності вищої освіти в США. Назва Ліга Плюща походить від густих зелених пагонів плюща, що обвивають старі будівлі університетів.

Велика кількість американських політичних діячів, відомих економістів, фінансистів, медиків і юристів пройшли навчання в одному з університетів Ліги Плюща. Університети, що входять до Ліги Плюща, є найстарішими ЗВО Америки. Усі вони розташовані на північному сході США
2.

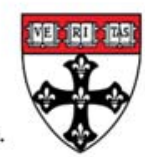

3.

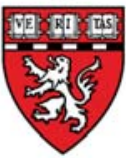

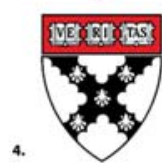
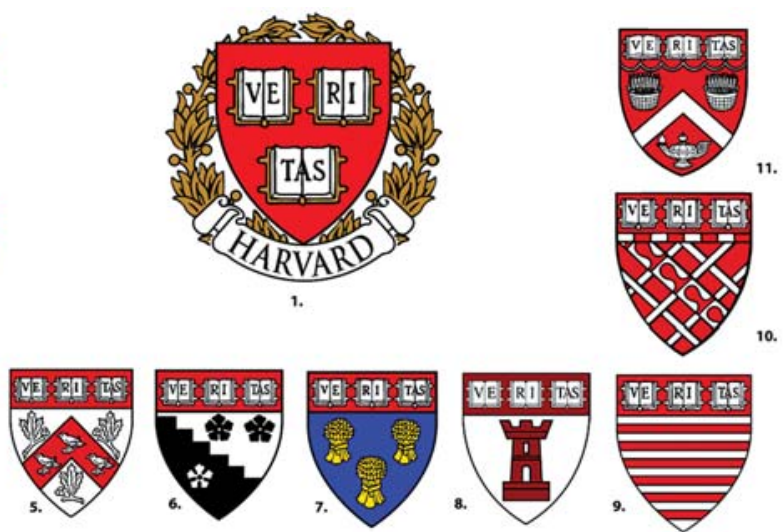

1.Ловний гер6 Гареардського університету. 2. Гер6 Гареардської школи громадського здоров'я. 3. Гер6 Гареардської медичної школи. 4. Тер6 Гарвардської школи 6ізнесу. 5. Гер6 Гарвардської школи теологї. 6. Гер6 Гарвардської освітньої школи. 7. Гер6 Гарвараської шкопи права. 8. Гер6 Гарвардської школи стоматологї. 9. Гер6 Гарвардської школи управління імені Джона Ф. Кеннеді. 10. Гер6 Гарвардської школи дизайну. 11. Гер6 гареардськой школи неперервного навчання.

Рис. 3. Геральдичний комплекс Гарвардського університету 


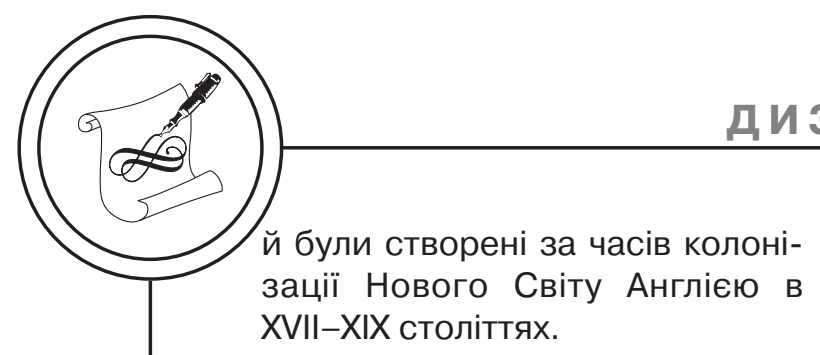

Важливими складовими якісної освіти вузів $€$ в першу чергу рівень підготовки викладацького складу та обсяг наукових досліджень. Серед випускників Ліги чимало нобелівських лауреатів, видатних науковців і лауреатів інших наукових премій. Крім того, всі університети Ліги - найбагатші приватні навчальні заклади в США та мають можливість виділяти власні гроші на здійснення багатьох наукових розробок і досліджень. Університети Ліги володіють величезними територіями, які вони отримали в користування від держави. Кожен кампус - це місто в місті, що має власні дослідні центри, музеї, бібліотеки, театри, комунікаційну та транспортну інфраструктуру. Кожен ЗВО випускає періодичні видання, має телебачення та радіо. Вартість навчання в університетах Ліги одна з найвищих у світі.

Герб цього університету розроблений і прийнятий на початку тридцятих років XX століття. Три білих кола, зображених на гербі, є фамільними символами сім'ї Вільяма Пена (засновника штату Пенсільванія); дельфін, розташований у верхній частині герба, $€$ сімейним символом Бенджаміна Франкліна - також засновника університету.

Як і на багатьох інших університетських гербах, розкриті книги символізують прагнення до осягнення знань. Кольори, що входять до гербових символів, $€$ одночасно барвами державного прапора США (червоний, білий, синій) й штату (синій і червоний).
Рішення про використання цих кольорів як офіційних барв університету було прийняте вкінці XIX століття. Девізу університету «Leges sine moribus vanae» («3aкони без моралі марні») більше трьохсот років.

Медичний факультет університету штату Пенсільванія є першим медичним факультетом у ЗВО США, тому до його студентів $€$ дуже високі вимоги, що не може не відобразитися на репутації випускників. Лікарі, які здобули освіту в університеті Пенсільванії, пишаються ім'ям і традиціями свого університету й протягом усього життя носять символіку своєї Alma mater.

Не менш цікава історія герба університету Ґлазґо. Студенти та викладачі цього ЗВО мають на своєму одязі герб, прийнятий ще в XV столітті. Деталі герба були ретельно опрацьовані та мають велике історичне й геральдичне значення. Зокрема, жезл (берло), зображений у центрі, - це найстаріший парадний жезл університету. Книга - традиційний символ знань і освіти. Птах на дереві й риба з кільцем у роті є деталями герба міста Ґлазґо; історія цих символів бере початок з легенди про покровителя Ґлазґо, св. Кентігерна. Девіз університету Ґлазґо «Via, Veritas, Vita» («Шлях, Істина, Життя») з'явився близько п'яти століть тому й розташовується на девізній стрічці під гербом. Ця фраза є цитатою з Нового Завіту («Я дорога, і правда, і життя» Євангеліє від Іоанна .14: 2) [2].

Опис і правила використання герба університету Ґлазґо прописані в низці суворих докумен- 
тів, що доводить серйозність підходу до історичних і геральдичних традицій цього ЗВО.

Медичний факультет Єльського університету, заснований у 1810 році, має герб від дня заснування. У його верхній частині розташовується герб засновника університету Елайджу Єля, стилізовані чорні хвости і червоний хрест св. Патрика. У нижній частині зображені жезл і змія Асклепія/ Ескулапа - символи медицини. Зелений колір вважається кольором медицини як науки, тому він був обраний для фону нижній частині герба [3].

Медичний факультет Єльського університету дотримується суворої політики щодо використання свого герба. За статутом факультету, герб можуть використовувати тільки співробітники факультету, студенти (для внутрішнього користування) та студентські організації, визнані деканатом. у всіх інших випадках для використання зображення герба необхідно особливий дозвіл адміністрації університету.

Не можна заперечувати необхідність символіки 3ВО, їі важливість та історичну значущість.

Геральдика та символіка надають індивідуальність і лягають у основу традицій. Символіка $€$ засобом об'єднання абсолютно різних людей, які бажають згадати веселі роки своєї молодості. Символіка університету пробуджує гордість за свою Alma mater, інтерес до її історії, а також породжує духовну єдність навчального закладу та його випускників.

Глибоку історію мають і традиції девізів ЗВО світу.

Першим європейським університетом вважається Болонський
Університет (м. Болонья, Італія) (Università di Bologna, UNIBO), заснований у 1088 році. Ректором медицини й вільних мистецтв Болонського університету, професором і віце-канцлером Істрополітанської академії в Братиславі, професором Краківського Яґеллонського університету був наш співвітчизник Юрій Донат Котермак з Дрогобича (1450-1494) [4, 5].

Девіз найстарішого університету Європи, Університету Болоньї:

«Alma mater studiorum - Petrus ubique pater legum Bononia mater»

(«Alma mater studiorum - Матигодувальниця вчення»)

Лондонська школа економіки

«Rerum cognoscere causa»

(«To understand the causes of things» - «Зрозуміти причини речей»)

Імперський коледж Лондона

«Scientia imperii decus et tutamen»

("Knowledge is the adornment and protection of the State» «Знання - прикраса й захист держави»)

Кембриджський університет

«Hinc lucem et pocula sacra»

(«From here, light and sacred draughts» - «Тут [ми знаходимо] світло та святі [знання]»)

Університет Оксфорда

«Dominus Illuminatio Mea»

(«Господь - просвічення MOє»)

Гарвардський університет

«Veritas»

(«/стина»)

Стенфордський університет

«Die Luft der Freiheit weht» (Девіз Стенфорда, як не дивно, німецькою - це цитата поетагуманіста Ульріха фон Ґуттена)

(«Віє вітер свободи») 


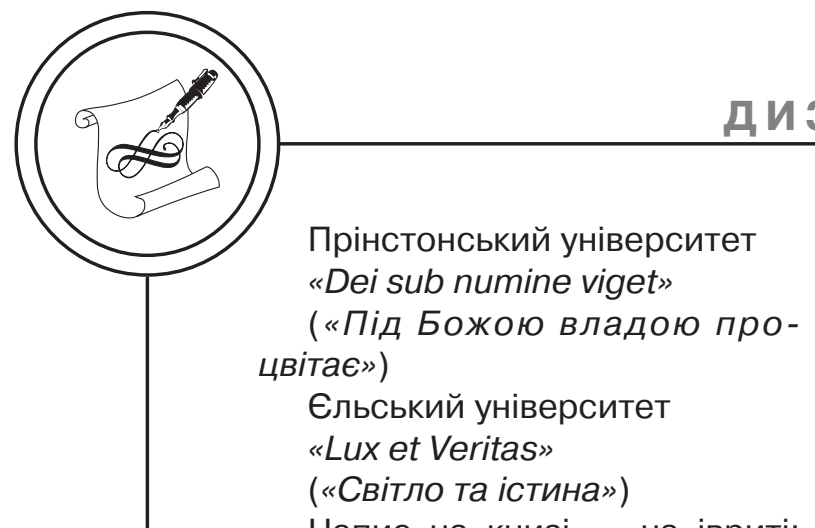

Напис на книзі - на івриті: УРІМ I ТУММІМ, що можна перевести як «орел або решка».

Массачусетський технологічний інститут

«Mens et Manus»

(«Головою та руками»)

Каліфорнійський технологічний інститут

«The truth shall make you free»

(«Правда дає свободу»)

Університет Берклі, Каліфорнія «Fiat LuX»

(«Хай буде світло»)

Гейдельберзький університет «Semper Apertus Immer offen» («Книга знань завжди відкрита»)

Тюбінґенський університет «Attempto!»

(«Дерзаю!» Або «Наважуюся!»)

Університет Неймегена, Нідерланди (Radboud Universiteit Nijmegen)

«In Dei nomine feliciter»

(«На щастя в ім'я Бога»)

Університет Країни Басків (Universidad del Pais Vasco)

«Eman ta zabal zazu»

(«Давайте знання і розширюйте їх»)

Фразу було запозичено з гімну басків.

Мадридський університет імені Карлоса III (Universidad Carlos III de Madrid)

«Homo homini sacra res»

(«Людина повинна бути священною для людини»)

Університет Калґарі (Канада) «Mo Shjile Togam Suas»

(«Я підніму очі»), девіз шотландською (ґельською) мовою, хоча офіційними мовами Канади $\epsilon$ англійська та французька.

Технічний Університет Ейндховена (Нідерданди)

«Mens Agitat Molem»

(«Дух рухає матерією»)

Ессекскій Університет (University of Essex)

«Thought the harder, heart the keener»

(«Сміливіше думка, i серце чуттєвіше»)

Федеральний університет Еспіріту-Санту (Святого Духа), Бразилія (Universidade Federal do Espirito Santo)

«Docete Omnes Gentes»

(«Вчіть всіх людей»)

Лісабонський університет

«Ad lucem»

(«Сонце сходить для всіх»)

Падуанський університет, Італія

«Universa Universis Patavina Libertas»

(«Вільний університет Падуї, загальний $і$ для всіх»)

Прийнято вважати, що корпоративна культура $є$ характерною для ЗВО системою цінностей, ідеалів, норм, установок, поглядів, переконань, стандартів роботи, стилів поведінки, традицій, звичаїв, ритуалів, заходів, символів, морально-психологічного клімату. Корпоративна культура - це спосіб життя, мислення, дії колективу, отже, вона представляється як всеохоплююче явище, що впливає на університетське життя в цілому [6-10].

Не менш важливим у просуванні брендів університетів $€$ наявність розвиненого корпоративного стилю ЗВО, адже осми- 
слена й наступальна політика презентації ЗВО на ринку освіти $€$ ознакою часу.

За 28 років незалежності українські ЗВО створили чимало символів і атрибутики, проте більшість з них далекі від досконалості, здебільшого несуть у собі риси доморощеності й непрофесіоналізму, замість продуманого лаконізму, занадто багатослівні й недоречно пафосні, тому назріла необхідність якісно нового підходу до створення й розвитку символіки ЗВО. Адже амбітні плани України та її вищої школи щодо інтеграції в європейський і світовий цивілізований процес потребують фахового високого рівня зовнішньої атрибутики такого інтегрування.

Наприкінці варто зупинитися на символіці Національного технічного університету України «Київський політехнічний інститут імені Ігоря Сікорського».

Нею віддавна $€$ емблема, створена приблизно 1902 року, при спорудженні основного кор- пусу КПІ ім. Ігоря Сікорського. Ця емблема $є$ гербом, бо містить характерні ознаки геральдичної композиції - наявність гербового щита, розтятого та перетятого на чотири поля із геральдичними фігурами, що символізують певні види навчання та діяльності. Цей герб офіційно ніколи не затверджували, але він присутній у зовнішній презентації КПІ ім. Ігоря Сікорського від декору внутрішніх приміщень до логотипів різних студентських об'єднань (рис. 4).

Фрагментарна шестерня в гербі відображає механічне відділення, сокира - інженерну (первісно - саперно-інженерну) діяльність, селянські вила - сільськогосподарський напрямок і фігурна колба Кляйзена - хімічне відділення.

Щодо нинішнього стану справ з емблематикою та символікою КПІ ім. Ігоря Сікорського спостерігається певна неузгодженість і плутанина. На офіційному сайті КП। ім. Ігоря Сікорського читаємо

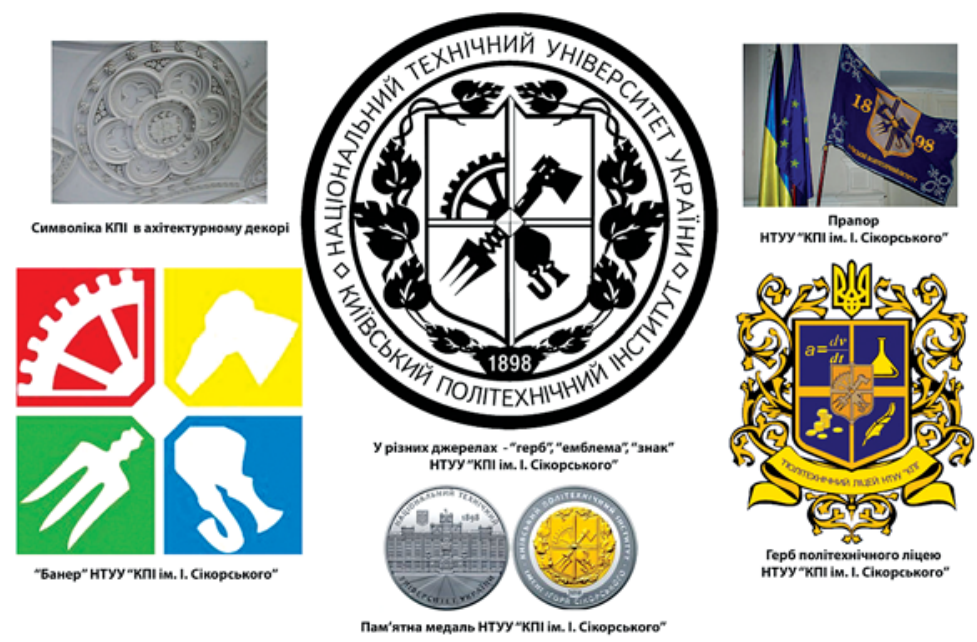

Рис. 4. Варіанти використання символіки КПІ ім. Ігоря Сікорського 
наступне: «Навчальні підрозділи КПІ ім. Ігоря Сікорського мають свої офіційні візитівки, що відображають напрям їхньої діяльності.

У червні 2010 р. завершилася підготовка 26 емблем факультетів та інститутів Університету. Організаційна робота зі створення єдиного реєстру, узгодження та затвердження емблем виконувалася під керівництвом головного архітектора КП। ім. Ігоря Сікорського В. І. Лиховодова за творчою участю деканів факультетів і директорів інститутів фахівців О. О. Лебедєвої, О. В. Шеляга, С. М. Снєжкіна. Емблеми розроблено в двох варіантах кольорові та чорно-білі.

Після затвердження розпорядженням ректора зразки емблем у друкованому та електронному вигляді передано в архів університету на постійне зберігання, електронні версії - керівникам факультетів та інститутів для використання (рис. 5).
Прапор Національного технічного університету України «Київський політехнічний інститут ім. Ігоря Сікорського» - сапфірового кольору. У центрі - схематичне зображення герба КП। ім. Ігоря Сікорського на білому тлі із золотими лініями.

Банер - графічне зображення рекламного характеру. Як банер КПІ ім. Ігоря Сікорського використовуються варіації логотипу Університету».

Отже, в одному тексті про один і той же символ пишеться і «емблема», i «герб», i, приблизно, з тим же наповненням фігурує й «банер». При відкриванні рубрики «Герб» цитується Конституція України з описом Герба України, а емблема чи герб КП। ім. Ігоря Сікорського наводиться лише у вигляді зображення без опису й без наведення документу (piшення Вченої ради, розпорядження ректора тощо), яким він затведжений.
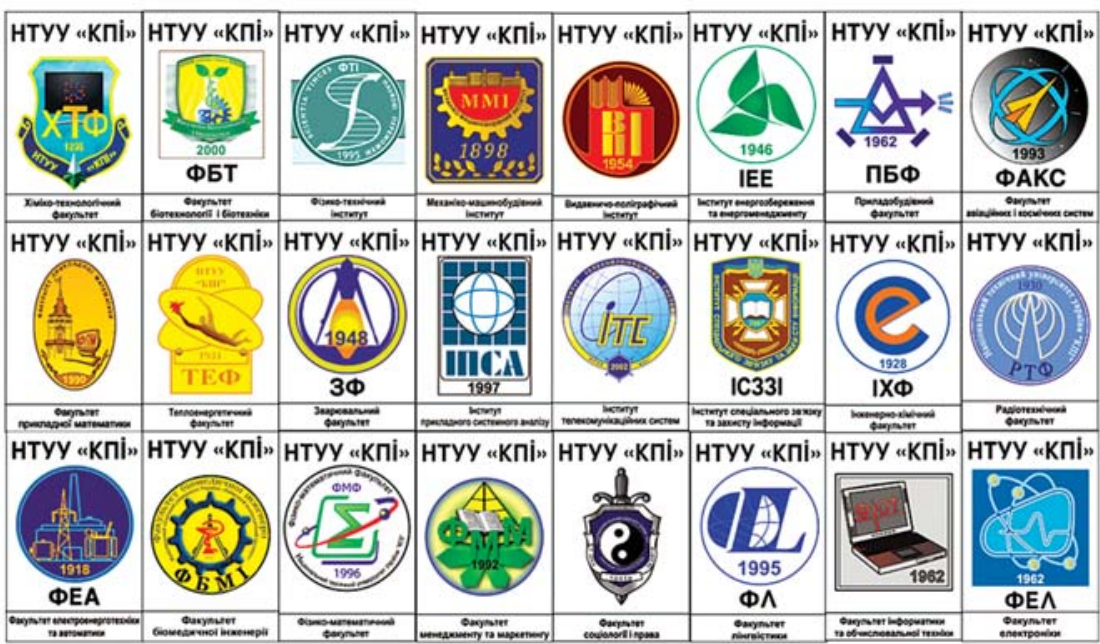

Рис. 5. Емблеми та гербоподібні знаки факультетів КП। ім. Ігоря Сікорського 
Опис прапора не відповідає вексилологічним нормам, полотнище прапора назване «сапфіровим», а опис існующого герба чи емблеми не відповідає їх зображенню.

Неофіційним символом проголошено навіть білок, що мешкають у парку Університету.

Щодо емблем і логотипів факультетів - це випадкові символи, які важко порівнювати 3 геральдичними символами світових університетів.

На думку автора та його однодумців, емблема мала би лишатися в символіці КПІ ім. Ігоря Сікорського як сталий артефакт з минулого, адже вона не повною мірою відіграє роль головної іміджевої зовнішньої презентації Університету, зокрема не враховує факт присвоєння Університету почесного найменування «імені Ігоря Сікорського», що було би вкрай важливим до просування бренду КПІ ім. Ігоря Сікорського як загальносвітового. Адже постать Ігоря Сікорського й сама по собі є брендом.

Протягом 2010-2018 рр. авторам разом зі студентами та викладачами ВПІ КПІ ім. Ігоря Сікорського здійснювалися спроби створення герба Університету з урахуванням його нового статусу. Найбільш зрілою видається спроба 2018 року, здійснена кафедрою графіки ВПІ за участі студентів М. Маєвської та М. Плюто (рис. 6).

Опис проекту звучав так: «В основу розробки символіки КП। ім. Ігоря Сікорського покладено ідеї спадкоємності історичної емблеми Університету, об'єднання безсумнівних брендів світового значення - КПІ та присвоєного Університету почесного найменування імені Ігоря Сікорського.

Гербовий щит містить гербову фігуру, що $є$ відображенням візуального образу першооснови технічної науки - креслення.

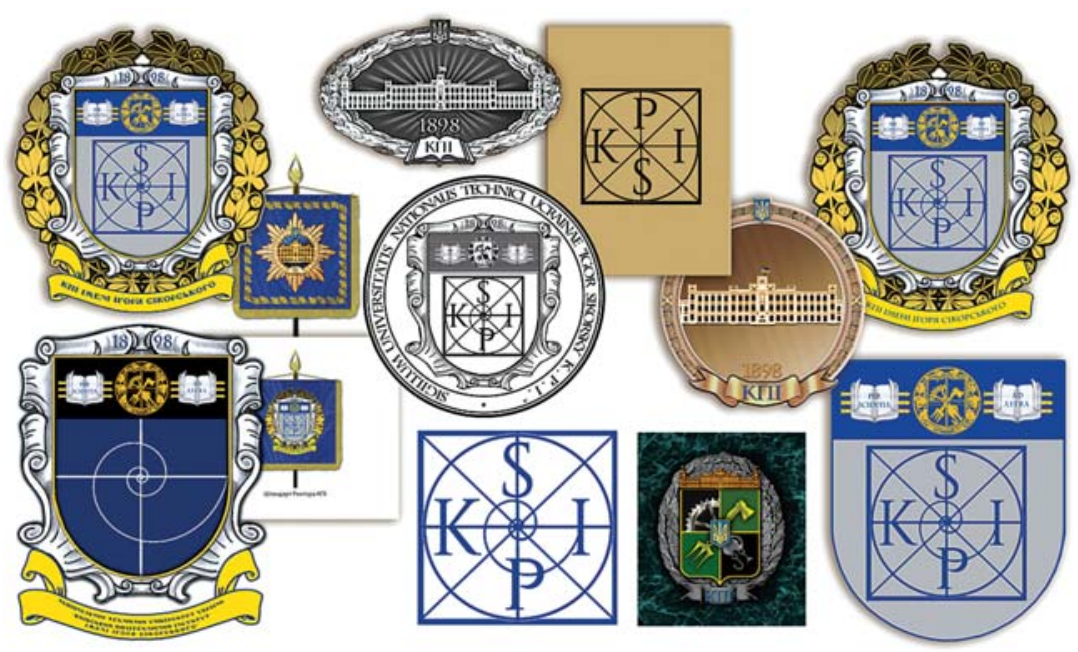

Рис. 6. Пошуки символіки КПІ ім. Ігоря Сікорського у виконанні студентів та викладачів кафедри графіки ВП। 
Додатково квадрат - символ стабільності та ґрунтовності, відображенням чотирьох наукових чеснот - мудрості, інтелекту, знання, розсудливості. «Квадратом генія» називають поєднання розуму та волі. Ігор Сікорський, видатний випускник КПІ, ім'я якого носить Університет, любив згадувати, що настільною книжкою його дитинства була подарована батьками збірка малюнків і креслень Леонардо да Вінчі. Особливо юного Сікорського вразили розробки теорії польоту Леонардо да Вінчі та найголовніше - спіралеподібного обертання гвинта літального апарату, названого «гелікоптер». Видатний конструктор літаків і гелікоптерів, Сікорський підняв у повітря перший свій гелікоптер VC-300 1939 року й досяг зеніту слави як творець корпорації Sikorsky Aircraft, яка відома як лідер гелікоптеробудування у світі.

Власне, спіралеподібний рух лінії польоту гелікоптера, є ще втіленням ідеї про досконалість. Адже спіраль «золотого перетину» або «спіраль Фібоначчі» вважають всесвітнім символом ідеальної гармонії та пропорційності, науки та поступу. У поєднанні з «квадратом генія» Леонардо пов'язує новостворену символіку герба $з$ історичною емблемою КПІ ім. Ігоря Сікорського.

Емблема займає своє гідне місце в главі гербового щита. Супроводжують ї̈ класичні символи науки та навчання - книги.

Девіз «PAR SCIENTIAAD ASTRA»

$€$ перефразованою класичною латинською сентенцією «PER ASPERA AD ASTRA» - «Через терни до зірок». Оскільки, наука $€$ суттю навчання в КП ім. Ігоря
Сікорського, такий девіз найкраще підходить для ЗВО, а завершення девізу «до зірок» несе два сенси - діяльність Ігоря Сікорського була спрямована на політ, досягення зірок, та й сам він $€$ зіркою першої величини у сфері науки, техніки та інженерії.

Нині бренд Igor Sikorsky належить світовому лідеру з ракетних та аерокосмічних технологій Lockheed Martin Corporation американській компанії, що спеціалізується на галузі авіабудування, авіакосмічної техніки, суднобудування, автоматизації поштових служб і аеропортової логістики.

Каштановий вінок повного герба є даниною тому факту, що КПІ ім. Ігоря Сікорського один з найстаріших ЗВО столиці України міста Києва, славнозвісним рослинним символом якого $є$ каштанове листя.

Символіка барв і металів.

Лазур, синій колір - втілення духовності, небесної висоти, шляхетності.

Золото, жовтий колір - символ щедрот, багатства, різноманітності, процвітання.

Срібло - символ чистоти, чеснот, шляхетності, «білизни» духовної та тілесної.

Поєднання синього кольору та золота відповідає національній символіці України. Поєднання срібла та синього кольору відповідає кольорам Києва срібний Архістратиг Михайло в синьому полі гербового щита.

Втім, рішення стосовно ребрендингу КПІ ім. Ігоря Сікорського так за ці роки й не було прийняте, тому залишимо цей опис і зображення як нагадування про важливість уявлень про КП। iм. Ігоря Сікорського як бренд 
не тільки всередині України, але й у зовнішньому світі та про необхідність просування цього бренду, покращення іміджевої ідентифікації Університету у тому числі, за допомогою символіки та атрибутики. Цікаво, що за час спроб вдосконалення символіки КПІ ім. Ігоря Сікорського автор цієї публікації став автором символіки низки закладів вищої освіти та деяких ліцеїв України Київського національного торговельно-економічного університету України; Державного лінгвістичного університету України; Одеської національної академії харчових технологій; Військового інституту телекомунікацій та інформатизації імені Героїв Крут тощо.

\section{Висновки}

Проаналізовано кращі зразки символіки ЗВО деяких країн, а також стан появи та функціонування символіки КПІ ім. Ігоря Сікорського.

Зроблено висновок про якнайчастіше використання саме геральдичних символів у брендуванні лідерів світового освітнього ринку та найбільш рейтингових ЗВО за класифікацією довідника «The Times Higher Education World University Rankings».

Досліджено деякі невідповідності в унормуванні використання емблематики КПІ ім. Ігоря Сікорського, надано інформацію про спроби іï̈ переосмислення протягом 2009-2018 років.

\section{Список використаної літератури}

1. O. Neubecker, J. P. Brook-Little. Heraldry. Sources, symbols and meaning. Tiger Books, 1997. pp. 54-67.

2. Wagner A. R. Heralds and Heraldry in the Middle Ages. 2 ed. Oxford, 1956, p. 76.

3. Pastoureau M. Traite d'Heraldique. 2 ed. Paris, 1993. p. 16.

4. Galbreath DL, Jequier L. Manuel du Blason. Lausanne, 1977. p. 23.

5. Giovanni Santi-Mazzini. Araldica. Storia, linguaggio, simboli e significati dei blasoni e delle armi. Milano, Mondadori, 2003.

6. О. Руденко. Геральдика як знакова система в сучасному оформленні друкованих видань / О. Руденко, О. Кірдіна // Антиквар. 2016. № 1.

7. Alfred Znamierowski. Insygnia, symbole i herby Polskie. Warszawa, 2003.

8. Georg Scheibelreiter. Heraldik. Wien, München. 2006.

9. Каталог виставки «1000 років української печатки». Національний музей історії України (24 травня-15 листопада 2013 р.).

10. А. Ґречило. Наш герб. Українськи символи від княжих часів до сьогодення / Андрій Ґречило, Богдан Завітій. Київ: В-во «Родовід». 2018.

\section{References}

1. Neubecker, O. \& Brook-Little, J. P. (1997). Heraldry. Sources, symbols and meaning, 54-67 [in English].

2. Wagner, A. R. (1956). Heralds and Heraldry in the Middle Ages, 76 [in English].

3. Pastoureau, M. (1993). Traite d'Heraldique. Paris, p. 16 [in Franch].

4. Galbreath, DL \& Jequier, L. (1977). Manuel du Blason. Lausanne, p. 23 [in Franch]. 
5. Santi-Mazzini, G. (2003). Araldica. Storia, linguaggio, simboli e significati dei blasoni e delle armi. Milano, Mondadori [in Italian].

6. Rudenko, O. \& Kirdina, O. (2016). Heraldyka yak znakova systema v suchasnomu oformlenni drukovanykh vydan. Journal of Antykvar, 1 [in Ukrainian].

7. Znamierowski, A. (2003). Insygnia, symbole i herby Polskie. Warszawa [in Polish].

8. Scheibelreiter, G. (2006). Heraldik. Wien, München [in German].

9. (2013). Kataloh vystavky '1000 rokiv ukrainskoi pechatky'. Natsionalnyi muzei istorii Ukrainy [in Ukrainian].

10. Grechylo, A. \& Zavitii, B. (2018). Nash herb. Ukrainsky symvoly vid kniazhykh chasiv do sohodennia. Kyiv: V-vo 'Rodovid' [in Ukrainian].

Проанализирована история создания емблематики высших учебных заведений некоторых стран, системность подходов

к их знаковым и геральдическим системам, созданию

брендированных эмблематических корпоративных конвенциональных средств визуальной идентификации. Изучена история емблематики КПИ им. Игоря Сикорского, попытки нормализации эмблемы Университета и предложены пути совершенствования системы визуальной презентации учреждения высшего образования с мировым именем.

Ключевые слова: символика; геральдический комплекс; имиджевая презентация; брендинг; университет.

The features of branding as a technology of promotion of the institution of higher education in the market of educational services are considered. The views of the Igor Sikorsky KPI coat-of-arms and logo are being investigated.

Keywords; symbolism; heraldic complex; image presentation; branding; university. 